Marquette University

e-Publications@Marquette

College of Education Faculty Research and

Publications

Education, College of

4-1-2003

\title{
Addressing Health Disparities in Middle School Students' Nutrition and Exercise
}

\author{
Marilyn Frenn \\ Marquette University, marilyn.frenn@marquette.edu \\ Shelly Malin \\ Marquette University \\ Naveen K. Bansal \\ Marquette University, naveen.bansal@marquette.edu \\ Mary Delgado \\ Milwaukee Public Schools \\ Yvonne Greer \\ Milwaukee Health Department \\ See next page for additional authors
}

Accepted version. Journal of Community Health Nursing, Vol. 20, No. 1 (Spring 2003): 1-14. DOI. (C) 2003 Taylor \& Francis. Used with permission. 
Authors

Marilyn Frenn, Shelly Malin, Naveen K. Bansal, Mary Delgado, Yvonne Greer, Michael Havice, Mary Ho, and Heidi Schweizer 


\title{
Addressing Health Disparities in Middle School Students' Nutrition and Exercise
}

\author{
Marilyn Frenn \\ College of Nursing, Marquette University \\ Milwaukee, WI \\ Shelly Malin \\ College of Nursing, Marquette University \\ Milwaukee, WI \\ Naveen Bansal \\ Department of Mathematics, Marquette University \\ Milwaukee, WI \\ Mary Delgado \\ Milwaukee Public Schools \\ Milwaukee, WI \\ Yvonne Greer \\ Milwaukee Health Department \\ Milwaukee, WI \\ Michael Havice \\ College of Communication, Marquette University \\ Milwaukee, WI \\ Mary Ho \\ Asthma/Allergy Center, Medical College of Wisconsin \\ Milwaukee, WI
}

Journal of Community Health Nursing, Vol. 20, No. 1 (Spring 2003): pg. 1-14. DOI. This article is @ Taylor \& Francis and permission has been granted for this version to appear in e-Publications@Marquette. Taylor \& Francis does not grant permission for this article to be further copied/distributed or hosted elsewhere without the express permission from Taylor \& Francis. 
NOT THE PUBLISHED VERSION; this is the author's final, peer-reviewed manuscript. The published version may be accessed by following the link in the citation at the bottom of the page.

\section{Heidi Schweizer \\ School of Education, Marquette University \\ Milwaukee, WI}

Those with low income, especially women of African American and Hispanic heritage have the greatest risk of inactivity and obesity. A 4-session (Internet and video) intervention with healthy snack and gym labs was tested in 2 (gym lab in 1) urban low-middle-income middle schools to improve low fat diet and moderate and vigorous physical activity. 1 The gym lab was particularly beneficial $(p=.002)$. Fat in diet decreased with each Internet session in which students participated. Percentage of fat in food was reduced significantly $p=.018$ for Black, White, and Black/Native American girls in the intervention group. Interventions delivered through Internet and video may enable reduction of health disparities in students by encouraging those most at risk to consume $30 \%$ or less calories from fat and to engage in moderate and vigorous physical activity.

One in five adolescents (21\%) in the United States is overweight (National Center for Health Statistics, 1999). Patterns established during middle school years are important in the development of adult health-related habits (Leger \& Nutbeam, 2000). Given that poor diet, obesity, and inactivity result in more than 300,000 preventable deaths per year and that chronic disease accounts for $60 \%$ of medical care expenditures in the United States (National Center for Disease Prevention \& Health Promotion, 2001a), high priority must be given to developing effective interventions. Nearly half of American youths aged 12 to 21 years, lack vigorous activity on a regular basis. Inactivity is more common among women (14\%) than men (7\%) and among Black women (21\%) than White women (12\%). Participation in all types of physical activity declines strikingly as age or grade in school increases (National Center for Chronic Disease Prevention \& Health Promotion, 2001b). Extensive reviews (Contento et al., 1995; Kennedy, 1998; Meininger, 1997) of research on the effectiveness of nutrition education revealed many studies in which nutrition knowledge and attitudes of children were improved. School-based interventions were more effective than interventions conducted outside the school setting (Contento et al., 1995).

Journal of Community Health Nursing, Vol. 20, No. 1 (Spring 2003): pg. 1-14. DOI. This article is @ Taylor \& Francis and permission has been granted for this version to appear in e-Publications@Marquette. Taylor \& Francis does not grant permission for this article to be further copied/distributed or hosted elsewhere without the express permission from Taylor \& Francis. 
Harrell, McMurray, Gansky, Bandiwala, and Bradley (1999) demonstrated population-based approaches in schools are more effective than intervening with those at most risk for cardiovascular disease. Dietz and Gortmaker (2001) identified the great impact of school-based approaches, but noted that study findings often are not implemented.

\section{Conceptual Framework for the Intervention}

The intervention in this study incorporated concepts from the Transtheoretical (TM; Prochaska et al., 1994) and Health Promotion (HP; Pender, 1996) models, and was tailored to participants' stage of change. Conceptual development and prior work with these models have been described (Bowen, Meischke, \& Tomoyasu, 1994; Brug, Hospers, \& Kok, 1997; Cardinal, 1997; Cardinal, Engels, \& Zhu, 1997; Frenn \& Malin, 1998, in press; Frenn, Malin, \& Bansal, in press; Frenn \& Porter, 1999; Garcia et al., 1995; Greene et al., 1999; Lamb \& Joshi, 1996; Marcus, Eaton, Rossi, \& Harlow, 1994; Marcus \& Simkin, 1994; Nigg \& Courneya, 1998; Rossi, Greene, et al., 1994; Potvin, Gauvin, \& Nyuyen, 1997; Robbins et al., 2001; Steptoe, Wijetunge, Doherty, \& Wardle, 1996). Briefly, stages of change in the TM (Prochaska et al., 1994) include the following: Precontemplation(PC)people may "wish" to change, but have no plans to do so in the next six months; Contemplation (C)-people seriously considering change within six months, but have no specific plans; Preparation $(P)$-people who state the intention to change within one month and/or have a prior unsuccessful attempt within last year; Action (A)-people actively engaging in the new behavior, experiences, or environment for one day to six months; Maintenance (M)-people sustaining the change six months or more.

Internet and video sessions for students in PC and C stages of change focused on raising awareness of current eating and exercise, identifying pros(or benefits) of both low fat diet and exercise, and overcoming cons (or barriers) to consuming low fat diets and participating in exercise. Those in $\mathrm{P}, \mathrm{A}$, and $\mathrm{M}$ stages of change were prepared as "peer models" and led the healthy snack and exercise labs with the assistance of senior nursing students and faculty. Online 
NOT THE PUBLISHED VERSION; this is the author's final, peer-reviewed manuscript. The published version may be accessed by following the link in the citation at the bottom of the page.

feedback was given to all students in the intervention for each Internet session.

\section{This Study}

A four-session (Internet and video) intervention with healthy snack and gym labs (gym lab in one school only) was tested in two urban low-middle income middle schools during the 2000-2001 academic year. The purpose was to examine improvement related to Healthy People 2010 Objectives (U.S. Department of Health \& Human Services, 2000) for low fat diet, moderate and vigorous physical activity. The research questions examined in this study were:

1. Immediately after the intervention, when compared with students in the usual school curriculum, will students who receive the intervention have (a) a significantly greater decrease in dietary fat intake (within a range of $20 \%-30 \%$ of total calories); and (b) greater duration of weekly moderate and vigorous physical activity (PA)?

2. Were there differences in response to the intervention for race, sex, income level, or school attended?

3. Did response to the intervention differ based on number of sessions or use of gym lab?

\section{Method}

\section{Design}

A quasi-experimental design was used with assignment to group by classroom. The intervention also took place in the classroom computer lab.

\section{Sample}

Following review and approval by the University's Institutional Review Board, the study sample was recruited from two urban schools in the Midwest. Entire classrooms of students were recruited to 
intervention or control groups based on classroom assignment to prevent diffusion of the intervention to the control group. The sample included 341 students. Because students had missing data for some instruments, listwise deletion to include all variables in analyses resulted in a sample of 67 for the intervention group and 63 for the control. Those included in all analyses were 58 African American, 47 White, 4 Hispanic, 9 Asian, and 4 Native American. Participants ranged in age from 12 to15, 90 in seventh grade, 33 in eighth grade, 56 were boys, 68 girls. Forty-one were eligible for free lunch, 15 reduced fee, and 68 had no reduction in fee.

\section{Measures}

The measures used, number of items, and Chronbach's alpha in this study sample are shown in Table 1 . Independent variables for both low fat and physical activity included: stage of change, decisional balance, and access. Dependent variables included: the Food Habits Questionnaire and the Child and Adolescent Activity Log (CAAL).

Independent variables. Staging questions used by Prochaska's team (Greene et al., 1999) were used with the addition of anchors, such as "at the beginning of the school year," to help students think about how much fat they were eating and how much physical activity they were engaging in six months ago. Participants describing themselves in the action or maintenance stages of change were restaged to precontemplation if their fat intake exceeded $30 \%$ according to the algorithm used by Rossi, Rossi, et al. (1994) or if their physical activity was less than 90 minutes for three days. In this study stages for low fat were coded: Precontemplation $=1$; Contemplation $=2$; Preparation $=3$; Action $=4$; Maintenance $=5$; such that a higher score indicated improvement in willingness to change to a diet composed of $30 \%$ or less calories from fat. Stages for exercise were the opposite, such that a lower score indicated maintenance of physical activity for more than six months.

Decisional balance is conceptualized in the TM (Prochaska et al., 1994) as the relative importance of pros and cons for making a behavior change (this relationship is conceptualized as benefitsbarriers ratio in the HP model). Pros and cons are reported separately,

Journal of Community Health Nursing, Vol. 20, No. 1 (Spring 2003): pg. 1-14. DOI. This article is @ Taylor \& Francis and permission has been granted for this version to appear in e-Publications@Marquette. Taylor \& Francis does not grant permission for this article to be further copied/distributed or hosted elsewhere without the express permission from Taylor \& Francis. 
higher scores indicate higher pros or higher cons. The problems in using test-retest with psychological measures in that participants' responses may change have long been acknowledged (Burns \& Grove, 1987). However, two week test-retest reliability was previously examined with 34 low income, culturally diverse middle school students: pros low fat $R=0.575, p=.003$; cons low fat $R=0.615, p$ $=.000$; pros exercise $R=0.318, p=.113$; and cons exercise $R=$ $0.423, p=.025$.

Access to low-fat foods is a HP model construct examining availability of low-fat foods such as skim or $1 \%$ milk, fruits and vegetables, foods that are baked or broiled rather than fried (Frenn \& Malin, in press). Access to exercise programs and facilities is a HP Model construct examining availability of such things as parks, playgrounds, recreational programs, and health clubs, such as the Boys and Girls club and YMCA (Frenn \& Malin, in press; Garcia et al., 1995). A higher score on each instrument indicated greater access. Test-retest in a previous sample with 34 culturally diverse middle school students was: access to low fat foods $R=.555, p=.000$; access to exercise facilities and programs $R=.407, p=.002$. In order not to ask more than one class period of participants for administration of instruments, the access instruments were only included on post-test because less time was required to complete the other instruments the second time and these surveys could be included.

Dependent variables. The Food Habits Questionnaire was used as discussed by Greene et al. (1999). This instrument includes a 21item series of questions about consumption of high and low fat foods with a five-option response format. Low fat items were reverse scored and an algorithm used to calculate percentage off at, such that the resulting total score indicated percentage of fat in diet during the last month. This instrument was found to have the same distributions of stage of change to low fat diet when tested with Block's Food Frequency Questionnaire modified to increase sensitivity to high fat foods (Greene et al., 1999).

The CAAL was used to collect the physical activity data. Participants were asked to check activities they had done the previous day for each of 7 days and circle the amount of time spent on each. 
The CAAL contains 21 activities commonly engaged in by middle school age youth and previously was found to correlate highly with exercise as measured by Caltrac accelerometers and with fitness as measured by a step test (Garcia et al., 1995). Similar to Garcia et al. (1995), participants who had completed 3 days of log data were included in the analysis. Because Healthy People 2010 objectives focus on increasing moderate and vigorous activity among youth, only moderate and vigorous activity were included in the analyses (U.S. Department of Health \& Human Services, 2000).

Measure of participation in the intervention. We did not wish to make a type III error in which the study outcomes are evaluated based on the number of interventions delivered, rather than the number in which participants actually participated (Resnicow et al., 1998). For that reason participants were asked to respond to questions in each module by recording their answers in notebooks provided and online. Participant responses were tallied on completion of the study to determine their level of participation.

\section{Procedures}

An interviewer read the survey aloud while students marked their responses from their own copy. An additional interviewer circulated around the room to answer questions, check for missing data, and check for pattern response completion without attention to the items (these surveys were not included in the analyses). Pre-and post-test data collection each lasted approximately $45 \mathrm{~min}$. The CAAL logs were completed for three school days requiring approximately 5 min each day. Participants received a fruit snack at pre-and post-test and those completing both received a two dollar coupon for use in the school bookstore.

The intervention was conducted in four Internet sessions plus a healthy snack session and a gym class (one school only) of approximately $50 \mathrm{~min}$ (six total sessions). Interventions were delivered in the classroom computer lab. Content for each session and video is shown in Table 2.

Journal of Community Health Nursing, Vol. 20, No. 1 (Spring 2003): pg. 1-14. DOI. This article is @ Taylor \& Francis and permission has been granted for this version to appear in e-Publications@Marquette. Taylor \& Francis does not grant permission for this article to be further copied/distributed or hosted elsewhere without the express permission from Taylor \& Francis. 
NOT THE PUBLISHED VERSION; this is the author's final, peer-reviewed manuscript. The published version may be accessed by following the link in the citation at the bottom of the page.

\section{Data Analyses}

Descriptive statistics were used to examine percentage fat in diet and duration of moderate and vigorous activity. CAAL activities include those of mild, moderate, and vigorous intensity activities. Moderate and vigorous activity were included in analyses because these reflect Healthy People 2010 goals for adolescents. Total activity was also analyzed, because this has value for improving health (Twisk, Kemper, \& van Mechelen, 2000). Statistical Package for the Social Sciences (SPSS) General Linear Model (GLM; SPSS, Inc., 1999) was used with age as a covariate to compare participants on variables by sex, race, eligibility for free or reduced fee lunch (proxy for family income), and school, as well as interactions among these demographic characteristics with response to the intervention. Pre-test data on each measure were subtracted from post-test data to create a difference score for analysis. The number of sessions with answers recorded in notebooks and online were summed.

\section{Results}

Findings of the study are described for each research question (RQ). Figures include those most at risk for obesity later in life: African American and Hispanic girls and those with low income.

RQ1: Immediately after the intervention, when compared with students in the usual school curriculum, will students who receive the intervention have a significantly greater decrease in dietary fat intake (within a range of $20 \%-$ $30 \%$ of total calories); and (b) greater duration of weekly moderate and vigorous PA?

The difference in percentage fat between the intervention and control groups as a whole was not significant. Mean percentage fat was $31 \%$ for the intervention group and $32 \%$ for the control on both pre- and post-test.

Both control and intervention groups decreased their amount of moderate and vigorous activity, but the level of decrease in moderate and vigorous activity was less among the intervention group ( -8.58 $\mathrm{min}$ ) as compared to the control $(-37.61 \mathrm{~min} ; p=.024)$.

Journal of Community Health Nursing, Vol. 20, No. 1 (Spring 2003): pg. 1-14. DOI. This article is @ Taylor \& Francis and permission has been granted for this version to appear in e-Publications@Marquette. Taylor \& Francis does not grant permission for this article to be further copied/distributed or hosted elsewhere without the express permission from Taylor \& Francis. 
NOT THE PUBLISHED VERSION; this is the author's final, peer-reviewed manuscript. The published version may be accessed by following the link in the citation at the bottom of the page.

RQ2: Were there differences in response to the intervention for race, sex, income level, or school attended?

There were significant interactions for the mean differences between demographic variables and the intervention and control groups. As shown in Figure 1, girls in the intervention group decreased their dietary fat in comparison to the control group $(p=.018)$ for African Americans, White, Hispanics, and Native Americans. There was also an interaction effect for access to low fat foods among race, sex, and group ( $p=.036)$. White, Hispanic, and Asian girls in the intervention group had greater access to low fat foods.

Boys in the control group decreased their fat more in each racial group. This may be explained by the fact that boys (except Blacks) in the intervention group reported less access to low fat foods than boys in the control group.

The response to the intervention differed in percentage fat in diet from pre-to post-test $(p=.002)$ between sexes at each school. No other variables differed significantly in this interaction. When a comparison of demographic variables and differences in stage, pros, cons, and fat in diet was conducted, there were significant differences in free lunch status $(p=.000)$ and age $(p=.000)$ between the schools (only seventh grade students were included in the first school that also had more students with low income, whereas seventh and eighth grade students were included in the second school).

There was also a significant $(p=.04)$ interaction among race, income, and group as shown in Figure 2, with the intervention group increasing physical activity among those with the lowest income for all races except Native Americans, whereas the opposite was true for the control group. Response to the intervention did not differ significantly by sex for physical activity.

RQ3: Did response to the intervention differ based on number of sessions or use of gym lab?

Individual school analyses demonstrated that the number of sessions students responded to the Internet program online and/or in

Journal of Community Health Nursing, Vol. 20, No. 1 (Spring 2003): pg. 1-14. DOI. This article is @ Taylor \& Francis and permission has been granted for this version to appear in e-Publications@Marquette. Taylor \& Francis does not grant permission for this article to be further copied/distributed or hosted elsewhere without the express permission from Taylor \& Francis. 
their notebook were associated with a decrease in their percentage fat in diet as shown in Figure 3.

The gym lab was only conducted in the first school. When demographic variables, as well as difference in exercise stage, pros, and cons, were regressed on differences in total activity, the only significant variable was whether or not a physical activity lab was used $(p=.002)$ with an adjusted $R 2=0.24 ; F(9,28)=2.325 ; p=.042$. Those with the peer-led gym lab increased their total physical activity, whereas those with only the Internet and video intervention decreased their total physical activity, but not as much as those in the control group as shown in Figure 4.

\section{Discussion}

The statistical analyses with significant interactions demonstrate that the effect of intervention varies from race to race and from boys to girls. Both the low fat diet and physical activity aspects of the intervention resulted in significantly better outcomes for all but one racial subgroup in girls, who have the greatest risk of obesity later in life.

The effectiveness of the intervention in reducing fat in diet increased with each additional session that students responded to online and/or in the notebook provided. Because the Healthy People 2010 target of $30 \%$ or less calories from fat (U.S. Department of Health \& Human Services 2000) was not reached with the four Internet sessions and videos tested, additional sessions should be added. Gortmaker et al.'s (1999) middle school diet and exercise intervention included 16 sessions, so more than the four examined in this study likely will be needed for maximal effectiveness using Internet and video delivery as well. Kumianyka et al.'s (2000) comprehensive review of dietary fat reduction intervention studies also noted greater effect with a greater number of intervention contacts.

This study adds to knowledge in that it is a short, conceptuallybased intervention that is an improvement over traditional education in reducing dietary fat and maintaining increased frequency of moderate and vigorous physical activity for those most at risk for 
obesity later in life. Dale and Corbin (2000) similarly found that the conceptual approach with ninth grade students resulted in less sedentary behavior among girls.

The study results depict the complexity of intervention research. Even a standardized intervention (with the same Internet and video content) interacts differently with sex, age, income, and race. To the degree schools differ on these demographic variables, there will also be different responses by school. Gordon-Larsen, McMurray, and Popkin (2000) identified the importance of such demographic factors in middle and high school students engaging in moderate and vigorous activity. An intervention that works with those at highest risk is important, given the lower amounts of moderate and vigorous exercise of Black and Hispanic adolescents.

There were no significant differences in intervention effectiveness whether or not the peer-led food lab was included. Because this is time, personnel, and resource intensive by comparison to the Internet sessions and videos, the latter type of sessions should be developed and tested in subsequent research.

The sample size in the first school was sufficient to examine physical activity variables with and without the peer lead gym lab. The lab was very effective, especially for girls and those with low income, both subgroups who are at greatest risk for lower activity and for obesity as they grow older. This aspect of the intervention was not reexamined in the second school, because there was not a way to access gym space during times for the computer classes wherein the intervention took place. Because nursing students assisted with the peer-led gym class, the personnel costs of this aspect of the intervention may require that such resources be allocated to schools with the lowest income students for the addition of a peer-led gym class, especially for girls.

\section{Limitations and Needs for Further Research}

This study was limited by the number of participants who completed all instruments with less than $20 \%$ missing data. Listwise deletion is used for multivariate analysis and the amount of missing

Journal of Community Health Nursing, Vol. 20, No. 1 (Spring 2003): pg. 1-14. DOI. This article is @ Taylor \& Francis and permission has been granted for this version to appear in e-Publications@Marquette. Taylor \& Francis does not grant permission for this article to be further copied/distributed or hosted elsewhere without the express permission from Taylor \& Francis. 
data in instruments greatly reduced the number of students whose data could be used for analysis. The resulting sample did not permit analyses of both diet and exercise variables in the same equation. $A$ larger study is warranted once additional sessions have been added to attain the $30 \%$ of fat in diet target in Healthy People 2010.

The low test-retest correlations for instruments, is a further study limitation. Burns and Grove (1987) questioned the use of such estimates of stability in paper and pencil tests measuring attitudes, because it is assumed the attitudes may change.

The sex differences in access that resulted in different responses to this intervention by boys compared with girls requires further examination. Especially in groups with low income and middle school aged children, who do not independently have access to foods and opportunities or equipment for exercise, the effectiveness of any intervention may be compromised if participants do not have access to necessary requisites for the behavior.

\section{Conclusion}

The exercise session with peer-led, physical activity lab was effective in increasing moderate and vigorous activity. The Internet content alone prevented decrease in exercise to the degree it occurred in the control group. Adding an additional Internet session focused on exercise may be helpful, because Internet sessions can be administered across many schools with less personnel and without access to a gym. Most important, the intervention examined in this study significantly reduced percentage of dietary fat among girls, who are at greatest risk of obesity in later life.

\section{Notes}

1. Funded in part by the Milwaukee Area Health Education Center and the State of Wisconsin. Requests for reprints should be sent to Marilyn Frenn, Marquette University, P.O. Box 1881, Milwaukee, WI 53201-1881. Email: marilyn.frenn@marquette.edu 
NOT THE PUBLISHED VERSION; this is the author's final, peer-reviewed manuscript. The published version may be accessed by following the link in the citation at the bottom of the page.

\section{References}

Baranowski, T., Cullen, K. W., \& Baranowski, J. (1999). Psychosocial correlates of dietary intake: Advancing dietary intervention. Annual Review of Nutrition, 19, 17-40.

Bowen, D.J., Meischke, H.,\& Tomoyasu, N.(1994).Preliminary evaluation of the processes of changing to a low-fat diet. Health Education Research, 9(1), 85-94.

Brug, J., Hospers, H. J., \& Kok, G. (1997). Differences in psychosocial factors and fat consumption between stages of change for fat reduction. Psychology \& Health, 12, 719-727.

Burns, N., \&Grove, S. K. (1987). The practice of nursing research: Conduct, critique and utilization. Philadelphia: W. B. Saunders.

Cardinal, B.(1997).Construct validity of stages of change for exercise behavior. American Journal of Health Promotion, 12(1), 68-74.

Cardinal, B., Engels, H. J., \& Zhu, W. (1997). Application of the transtheoretical model of behavior change to preadolescents' physical activity and exercise behavior. Pediatric Exercise Science, 10(1), 6980.

Contento,I.,Balch,G.,Bronner,Y.,Lytle,L., Maloney,S.,Olson,C., etal.(1995). Thee ffectivenessof nutrition education and implications for nutrition education policy: A review of research. Journal of Nutritional Education, 27(4), 191-199.

Dale, D., \& Corbin, C. B.(2000).Physical activity participation of high school graduates following exposure to conceptual or traditional physical education. Research Quarterly in Exercise \& Sports, 71, 61-68.

Dietz, W. H., \& Gortmaker, S. L. (2001). Preventing obesity in children and adolescents. Annual Review of Public Health, 22, 337-353.

Frenn, M., \& Malin, S. (in press). Diet and exercise in low income, culturally diverse middle school students. Public Health Nursing.

Frenn, M., \& Malin, S.(1998). Health promotion: Theoretical perspectives and clinical applications. Holistic Nursing Practice, 12, 1-8.

Frenn, M., Malin, S., \& Bansal, N. K. (in press). Stage based interventions for low fat diet with middle school students. Journal of Pediatric Nursing.

Frenn, M., Porter, C. P. (1999). Exercise and nutrition: What do adolescents think is important? Applied Nursing Research, 12(4), 179-184.

Garcia, A., Broda, M. A., Frenn, M., Coviak, C., Pender, N. J., \& Ronis, D. L. (1995). Gender and developmental differences in exercise beliefs among youth and prediction of their exercise behavior. Journal of School Health, 65(6), 213-219.

Gordon-Larsen, P., McMurray, R. G., \& Popkin, B. M. (2000). Determinants of adolescent physical activity and inactivity patterns. Pediatrics, 105(6).

Journal of Community Health Nursing, Vol. 20, No. 1 (Spring 2003): pg. 1-14. DOI. This article is @ Taylor \& Francis and permission has been granted for this version to appear in e-Publications@Marquette. Taylor \& Francis does not grant permission for this article to be further copied/distributed or hosted elsewhere without the express permission from Taylor \& Francis. 
NOT THE PUBLISHED VERSION; this is the author's final, peer-reviewed manuscript. The published version may be accessed by following the link in the citation at the bottom of the page.

Retreived August 1, 2000 from http://www.pediatrics.org/cgi/content/full/106/6/e83.

Gortmaker,S.L.,Peterson,K.,Wiecha,J.,Sobol,A.M.,Dixit,S.,Fox,M.K., etal.(1999

). Reducing obesity via a school-based interdisciplinary intervention among youth. Archives of Pediatric and Adolescent Medicine, 153, 975-983.

Greene, G. W., Rossi, S. R., Rossi, J. S., Velicer, W. F., Fava, J. L., \& Prochaska, J. O. (1999). Dietary applications of the stages of change model. Journal of the American Dietetic Association, 99, 673-678.

Harrell, J. S., McMurray, R. G., Gansky. S, A., Bangdiwala, S.I., Bradley, C.B. (1999).A public health vs. a risk-based intervention to improve cardiovascular health in elementary school children: The Cardiovascular Health in Children study. American Journal of Public Health, 89, 1529-1535.

Kennedy, C. M. (1998). Childhood nutrition. In J. J. Fitzpatrick (Ed.), Annual review of nursing research (Vol 16, pp. 3-38). New York: Springer.

Kumianyka, S. K., Bowen, D., Rolls, B. J., Van Horn, L., Perri, M. G., Czajikowski, S. M., et al. (2000). Maintenance of dietary behavior change. Health Psychology, 19, 42-56.

Lamb, R., \& Joshi, M. S. (1996). The stage model and processes of change in dietary fat reduction. Journal of Human Nutrition \& Dietetics, 9, 43-53.

Leger, L., \& Nutbeam, D. (2000). A model for mapping linkages between health and education agencies to improve school health. Journal of School Health, 70, 45-50.

Leiberman, D.A. (1997).Interactive video games for health promotion: Effects on knowledge, self-efficacy, social support, and health. In R. L. Street, W. R. Gold, \& T. Manning (Eds.), Health promotion and interactive technology: Theoretical applications and future directions (pp. 103120). Mahwah, NJ: Lawrence Erlbaum Associates, Inc.

Maibach, E., \& Parrott, R. L. (Eds.). (1995). Designing health messages: Approaches from communication theory and public health practice. Thousand Oaks, CA: Sage.

Marcus, B. H., Eaton, C. A., Rossi, J. S., \& Harlow, L. I. (1994). Self-efficacy, decision-making, and stages of change: An integrative model of physical exercise. Journal of Applied Social Psychology, 24, 489-508.

Marcus, B. H., \& Simkin, L.R. (1994).The transtheoretical model: Applications to exercise behavior. Medicine \& Science Sports \& Exercise, 26, 14001404.

Meininger, J. C. (1997). Primary prevention of cardiovascular disease risk factors: Review and implications for population-based practice.

Advance Practice Nurse Quarterly, 3, 70-79.

National Center for Disease Prevention and Health Promotion. (2001a). Physical Activity and good nutrition: Essential elements to prevent

Journal of Community Health Nursing, Vol. 20, No. 1 (Spring 2003): pg. 1-14. DOI. This article is @ Taylor \& Francis and permission has been granted for this version to appear in e-Publications@Marquette. Taylor \& Francis does not grant permission for this article to be further copied/distributed or hosted elsewhere without the express permission from Taylor \& Francis. 
NOT THE PUBLISHED VERSION; this is the author's final, peer-reviewed manuscript. The published version may be accessed by following the link in the citation at the bottom of the page.

chronic diseases and obesity. Retreived October 25, 2001 from http://www.cdc.gov/nccdphp/dnpa/dnpaaag.htm

National Center for Chronic Disease Prevention \& Health Promotion. (2001b). Physical activity and health: Adolescents and young adults. Retrieved October 25, 2001 http://www.cdc.gov/nccdphp/sgr/adoles.htm National Center for Health Statistics. (1999). Healthy People 2000 Review, 1998-99. Hyattsville, MD: Public Health Service.

Nigg, C. R., \& Courneya, K. S. (1998). Transtheoretical model: Examining adolescent exercise behavior. Journal of Adolescent Health, 22, 214224.

Pender, N. J. (1996). Health promotion in nursing practice (3rd ed). Stamford, CT: Appleton \& Lange.

Potvin, L., Gauvin, L., \& Nyuyen, N.M. (1997).Prevalence of stages of change for physical activity in rural, suburban and inner-city communities. Journal of Community Health, 22, 1-12.

Prochaska, J. O., Velicer, W. F., Rossi, J. S., Goldstein, M. G., Marcus, B. H., Rakowski, W., et al. (1994). Stages of change and decisional balance for 12 problem behaviors. Health Psychology, 13, 39-46.

Resnicow,K., Davis,M., Smith,M.,Lazarus-Yaroch,A., Baranowski, T.,Baranowski, J., et al.(1998). How best to measure implementation of school health curricula: A comparison of three measures. Health Education Research, 13, 239-250.

Robbins, L. B., Pender, N. J., Conn, V. S., Frenn, M. D., Neuberger, G. B., Nies, M. A., et al. (2001). Physical activity research in nursing. Image Journal of Nursing Scholars, 33, 315-321.

Rossi, S. R., Greene, G. W., Reed, G. R., Rossi, J. S., Prochaska, J. O., \& Velicer, W. F. (1994). Cross validation of a decisional balance measure for dietary fat reduction (abstract). Annals of Behavioral Medicine, 16 (suppl), 167.

Rossi, S. R., Rossi, J.R., Rossi-Delprete, L.M., Prochaska, J.O., Bonspach, S.W.,\& Carleton, R.A. (1994). A process of change model for weight control for participants in community-based weight loss program. International Journal of Addictions, 29, 162-177.

Sallis, J .F. (1993). Promoting healthful diet and physical activity. In S. G. Millstein, A. C. Petersen, \& E. O. Nightingale (Eds). Promoting adolescent health: Rationale, goals, and objectives (pp. 209-241). Washington, DC: The Carnegie Corporation.

SPSS, Inc. (1999). Statistical Program for the Social Sciences. Version 9.0. Chicago: Author.

Steptoe, A., Wijetunge, S., Doherty, S., \& Wardle, J. (1996). Stages of change for dietary fat reduction: Associations with food intake, decisional balance and motives for food choice. Health Education Journal, 55, 108-122.

Journal of Community Health Nursing, Vol. 20, No. 1 (Spring 2003): pg. 1-14. DOI. This article is @ Taylor \& Francis and permission has been granted for this version to appear in e-Publications@Marquette. Taylor \& Francis does not grant permission for this article to be further copied/distributed or hosted elsewhere without the express permission from Taylor \& Francis. 
NOT THE PUBLISHED VERSION; this is the author's final, peer-reviewed manuscript. The published version may be accessed by following the link in the citation at the bottom of the page.

Twisk, J. W .R., Kemper, H. C. G., \& van Mechelen, W. (2000). Tracking of activity and fitness and the relationship with cardiovascular disease risk factors. Medicine \& Science in Sports \& Exercise, 32, 1455-1461. U.S. Department of Health and Human Services, Office of Public Health and Science.(2000). Healthy People 2010. Washington, DC: US Government Printing Office.

\section{Appendix}

\section{Table 1: Reliability Measures in This Study}

\begin{tabular}{|c|c|c|c|}
\hline Scale & No. of Cases & No, of items & $a$ \\
\hline \multicolumn{4}{|l|}{ Independent Variables } \\
\hline Pros (benefits) of low fat diet & 253 & 9 & 81 \\
\hline Cons (bartiers) to low fat diet & 250 & 9 & .73 \\
\hline Access to low fat food & 233 & 9 & 75 \\
\hline Pros (benefits) of exercise & 240 & 9 & .80 \\
\hline Cons (benefits) to exercige & 242 & 8 & 75 \\
\hline Exercise access & 238 & 9 & .7 \\
\hline \multicolumn{4}{|l|}{ Dependent Variables } \\
\hline Food frequency questiomaire & 233 & 20 & 82 \\
\hline Child adolescerk activity log & 298 & 21 & .77 \\
\hline
\end{tabular}

Journal of Community Health Nursing, Vol. 20, No. 1 (Spring 2003): pg. 1-14. DOI. This article is @ Taylor \& Francis and permission has been granted for this version to appear in e-Publications@Marquette. Taylor \& Francis does not grant permission for this article to be further copied/distributed or hosted elsewhere without the express permission from Taylor \& Francis. 
NOT THE PUBLISHED VERSION; this is the author's final, peer-reviewed manuscript. The published version may be accessed by following the link in the citation at the bottom of the page.

\section{Table 2: Content Covered in Internet, Videos, and Lab Activities}

\begin{tabular}{|c|c|}
\hline $\begin{array}{l}\text { Session } 1 \text { The session is structured to be interactive and } \\
\text { incorporates multiple instructional methods (Leiberman, } 1997 \text { ) } \\
\text { Session content includes interesting facts about teens and fat in } \\
\text { diet, using the food pyramid to foster self-reevaluation, and } \\
\text { consciousness raising for benefits of a health diet. The fat content } \\
\text { in food, including those in fast food restaurants, is presented. } \\
\text { Students complete a 1-day food diary on the Internet sofware and } \\
\text { are given feedback regarding tat, calories, and nutritional quality to } \\
\text { further increasse their sel-reevaluabion. }\end{array}$ & $\begin{array}{l}\text { Vdeo } 1 \text { Student actors of various racialethnic heritages are } \\
\text { shown thinking about what they are eating (to foster } \\
\text { self-reevaluation and consciousness raising and improved } \\
\text { self-efficacy through vicaricus modeling). Students are reminded } \\
\text { to think about what they have eaten in relation to the food pyramid, } \\
\text { using verbal persuasion to foster sef-efficacy. Portion sizes of } \\
\text { foods in various cutures are shown trom the City of Milwaukee } \\
\text { Health Department ABC's program. }\end{array}$ \\
\hline $\begin{array}{l}\text { Session } 2 \text { The Internet session asiss students to identify foods } \\
\text { they have eaten from the food pyramid (to buid self-efficacy } \\
\text { through enactment of healthy choices). Students read labels of } \\
\text { common foods and identify the fat content on the Internet program } \\
\text { (to raise consciousness of fat in focds). Test tubes of fat displayed } \\
\text { in inappetizing ways elicit emotional arousal usetul in fostering } \\
\text { sell-eflicacy for healthier food choices. }\end{array}$ & $\begin{array}{l}\text { Vofeo } 2 \text { Qur feen fole models are shown thinking about what to } \\
\text { eat at a variety of fast food restaurants. The intent of this video is } \\
\text { to raise consciousness of ways to make healthier choices when } \\
\text { you do eat out, as wetl as improve self-efficacy through vicarious } \\
\text { modeling. }\end{array}$ \\
\hline 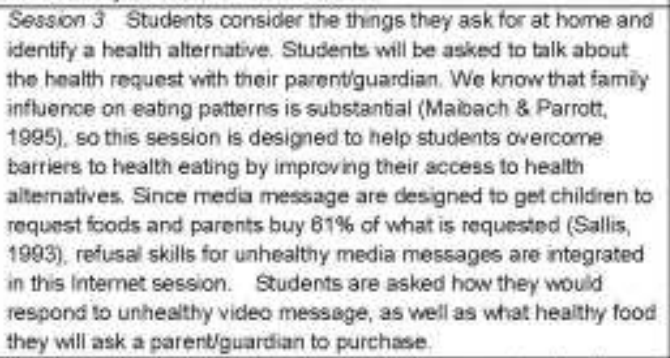 & $\begin{array}{l}\text { Video } 3 \text { This three-minute video is in a grocery store, whth a bad } \\
\text { dream sequence in which our character is chased by unhealthy } \\
\text { foods Our character slowly wakcs up choosing vogetables, fruits, } \\
\text { and whole grains. }\end{array}$ \\
\hline $\begin{array}{l}\text { Session } 4 \text { This session involves students in prepaning healthy } \\
\text { snacks in small groups lead by peer models with the assistance of } \\
\text { sonior nursing students. Peer models lead their group in } \\
\text { cakculating the total tat and calorie content of their snack, } \\
\text { distributing a sample at the end of the class. This session builds } \\
\text { sel.efficacy through enactment and is designed to help students } \\
\text { overcome barriers to eating healthy foods that they may not have } \\
\text { realized they like and can prepare themselves. Discussion of } \\
\text { ingredients and sharing of recipes that students can share wth } \\
\text { their familes is designed to promote access to healthy } \\
\text { alternatives, since not knowng how to prepare fruits and } \\
\text { vegetables is a barrier for adolescents in including these foods in } \\
\text { their diet (Baranowski. Cullen, } 8 \text { Baranowski. } 1989 \text { ). }\end{array}$ & $\begin{array}{l}\text { Vdeo } 4 \text { This 3-min video focuses on television, encouraging } \\
\text { students to ask for and do what is healthy, not what advertisers } \\
\text { ask them to do. Student actors asking for healthy foods, not } \\
\text { unheaithy foods, advertised are presented as a way to foster } \\
\text { selt-reevaluation. The video reinforces the idea that seventh } \\
\text { graders can increase theif access to healthy foods by asking their } \\
\text { parents/guardians for these foods, rather than products advertised. }\end{array}$ \\
\hline $\begin{array}{l}\text { Session } 5 \text { The Internet content focus is exercise for a healthy life } \\
\text { The session focus is consciousness raising and self-recvaluation } \\
\text { Moderate and vigorous exercise are described. Students are } \\
\text { asked to list activities they engage in. Feedback is given regarding } \\
\text { how much activity is recommended and the discussion among } \\
\text { students is focused on ways they each get this kind of exercise. } \\
\text { Students review their calorie intake along with how much moderate } \\
\text { and vigorous physical actwity they need to burn those calories. }\end{array}$ & $\begin{array}{l}\text { Video } 5 \text { This three-minute video shows a variety of physical } \\
\text { activities with a theme of "What is excercise?" This oontent fosters } \\
\text { selt-reeyaluation as students are encouraged to think about the } \\
\text { things they are doing to be physically active and additional ideas } \\
\text { they could corsider. Our purpose is to foster self-efficacy through } \\
\text { vicarious modeling and reinforce benefits of physical activity at } \\
\text { mild, moderate and vigorous levels. }\end{array}$ \\
\hline $\begin{array}{l}\text { Session } 6 \text { (onlly used in Schood 1) Consciousness Rasing } \\
\text { includes participation in peer-led activites during gym class. The } \\
\text { focus is on activites that are accessible and possible to perform } \\
\text { safely outside of school, so as to promote self-awareness of } \\
\text { lfelong opportunities for physical activity and the amount of } \\
\text { calories burned whice doing the activity for five minutes. Peer } \\
\text { models lead physical activities at stations in the gym assisted by } \\
\text { senior nursing students. }\end{array}$ & \\
\hline
\end{tabular}

Journal of Community Health Nursing, Vol. 20, No. 1 (Spring 2003): pg. 1-14. DOI. This article is @ Taylor \& Francis and permission has been granted for this version to appear in e-Publications@Marquette. Taylor \& Francis does not grant permission for this article to be further copied/distributed or hosted elsewhere without the express permission from Taylor \& Francis. 
NOT THE PUBLISHED VERSION; this is the author's final, peer-reviewed manuscript. The published version may be accessed by following the link in the citation at the bottom of the page.

Figure 1

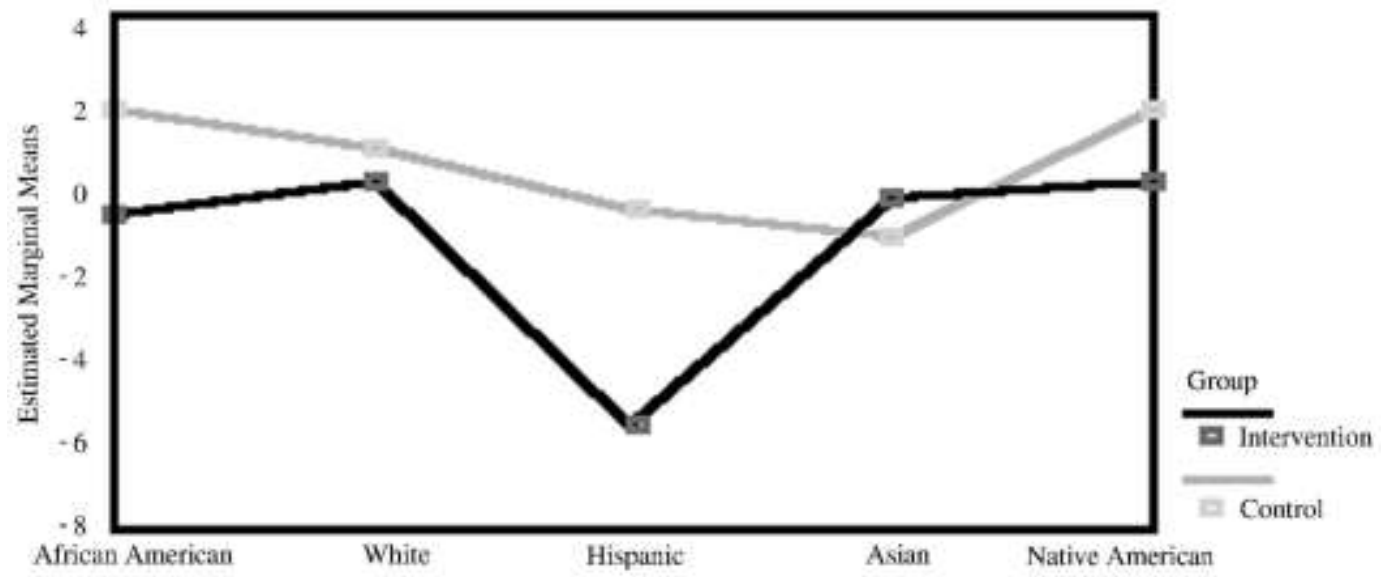

Differences in percentage fat in food by race for females. Pre-test levels were subtracted from post-test totals of percentage fat in food, so a lower number is the desired difference; 0 represents no change in percentage fat.

\section{Figure 2}

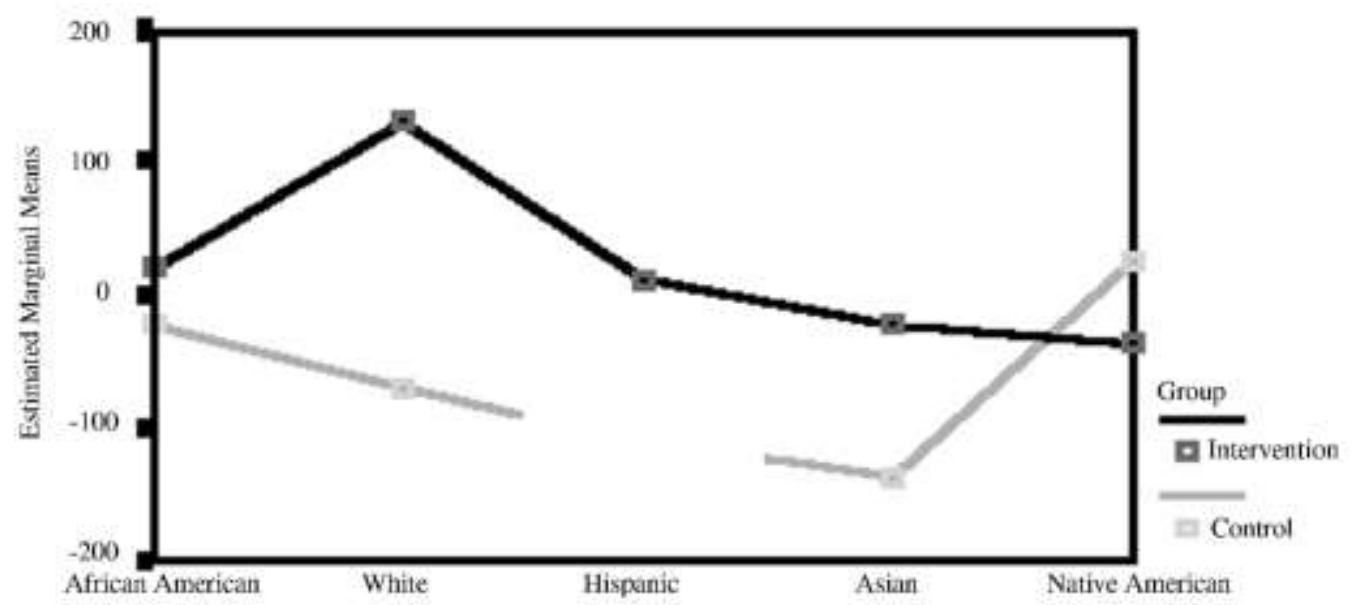

Differences in moderate/vigorous activity, by group, income, and race. Pre-test levels were subtracted from post-test totals of moderate vigorous activity, so a higher number is the desired difference; 0 represents no change in activity.

Journal of Community Health Nursing, Vol. 20, No. 1 (Spring 2003): pg. 1-14. DOI. This article is @ Taylor \& Francis and permission has been granted for this version to appear in e-Publications@Marquette. Taylor \& Francis does not grant permission for this article to be further copied/distributed or hosted elsewhere without the express permission from Taylor \& Francis. 
NOT THE PUBLISHED VERSION; this is the author's final, peer-reviewed manuscript. The published version may be accessed by following the link in the citation at the bottom of the page.

\section{Figure 3}

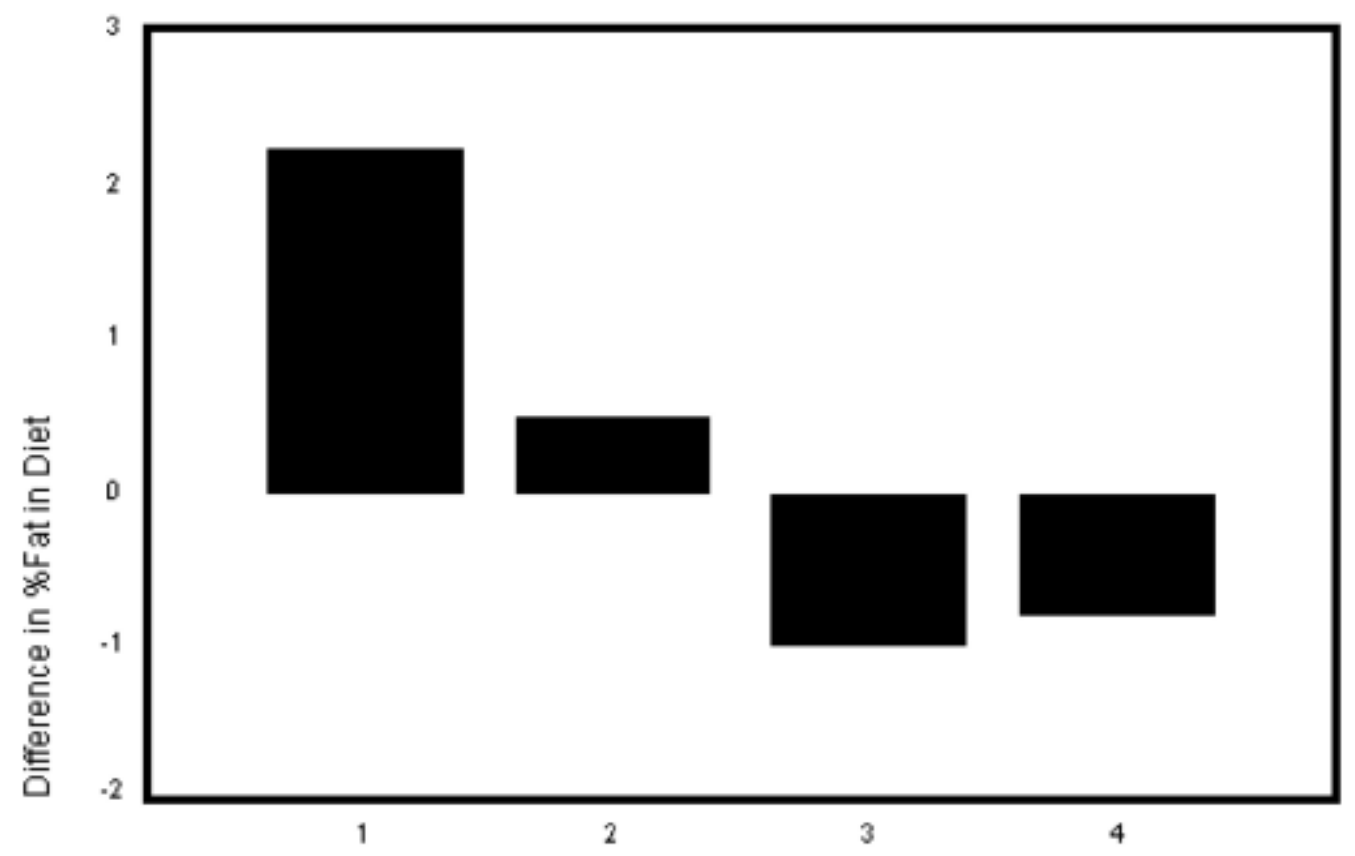

Relationships of decrease in percentage fat in diet to number of sessions in that students participated. Pre-test levels were subtracted from post-test totals of percentage fat in diet, so a lower number is the desired difference; 0 represents no change in percentage fat.

Journal of Community Health Nursing, Vol. 20, No. 1 (Spring 2003): pg. 1-14. DOI. This article is (C) Taylor \& Francis and permission has been granted for this version to appear in e-Publications@Marquette. Taylor \& Francis does not grant permission for this article to be further copied/distributed or hosted elsewhere without the express permission from Taylor \& Francis. 
NOT THE PUBLISHED VERSION; this is the author's final, peer-reviewed manuscript. The published version may be accessed by following the link in the citation at the bottom of the page.

\section{Figure 4}

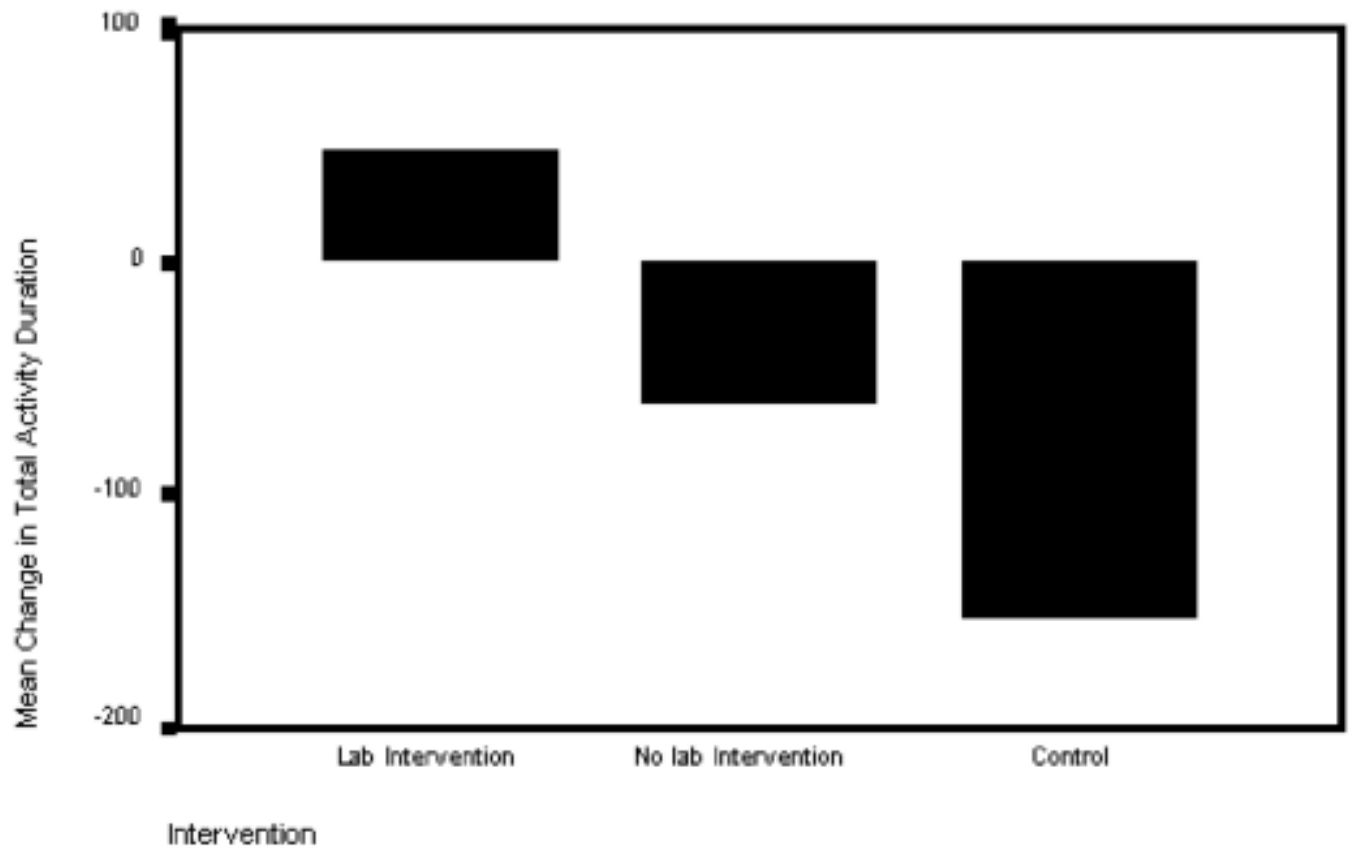

Differences in total change in activity with peer-led physical activity lab. Pre-test levels were subtracted from post-test totals of activity so a higher number is the desired difference; 0 represents no change in activity.

Journal of Community Health Nursing, Vol. 20, No. 1 (Spring 2003): pg. 1-14. DOI. This article is () Taylor \& Francis and permission has been granted for this version to appear in e-Publications@Marquette. Taylor \& Francis does not grant permission for this article to be further copied/distributed or hosted elsewhere without the express permission from Taylor \& Francis. 